\title{
The Effect of Mycorrhizal Fungal Strains on the Concentrations of Phosphorus and Selected Micronutrients in Tomato Fruit (Lycopersicon esculentum Mill.)
}

\author{
Joanna Majkowska-Gadomska ${ }^{1 *}$, Artur Dobrowolski' ${ }^{1}$, \\ Krzysztof K. Jadwisieńczak ${ }^{2}$, Anna Francke ${ }^{1}$ \\ ${ }^{1}$ Faculty of Agriculture and Forestry, Department of Agroecosystems and Horticulture, \\ University of Warmia and Mazury in Olsztyn, Prawocheńskiego 21, 10-957 Olsztyn, Poland \\ ${ }^{2}$ Faculty of Technical Science, Department of Heavy Duty Machines and Research Methodology, \\ University of Warmia and Mazury in Olsztyn Poland
}

Received: 8 May 2021

Accepted: 31 August 2021

\begin{abstract}
The research hypothesis postulates that mycorrhizal fungal strains can increase the content of phosphorus (P) and selected micronutrients in tomato fruit.

The aim of this study was to determine the suitability of three tomato cultivars for growing in a heated plastic tunnel, and to evaluate the influence of fungal strains applied to the rhizosphere of tomato plants on the concentrations of selected minerals, in particular $\mathrm{P}$, iron ( $\mathrm{Fe}$ ), manganese $(\mathrm{Mn})$, copper $(\mathrm{Cu})$ and zinc $(\mathrm{Zn})$, in the fruit. A two-factorial experiment was conducted in 2015-2016. Tomatoes were grown in coco coir in a heated plastic tunnel in the Experimental Garden of the University of Warmia and Mazury in Olsztyn. The first experimental factor were three tomato cultivars, 'Growdena $\mathrm{F}_{1}$, ' 'Listell $\mathrm{F}_{1}$ ' and 'Torero $\mathrm{F}_{1}$ ', suitable for growing in a controlled environment. The second experimental factor was growing tomatoes in coco coir mats with and without fungal strains: control treatment (without fungal strains), growth medium inoculated with fungi of the genus Glomus, growth medium inoculated with a combination of fungi of the genus Trichoderma. The experiment had a s split-block design, with 10 plants per replicate in each treatment. In order to determine the mineral content of tomato fruit, plant material was dried at a temperature of $65^{\circ} \mathrm{C}$ and ground in an electric mill. The samples were analyzed in the Chemical and Agricultural Research Laboratory in Olsztyn to determine their content of $\mathrm{P}, \mathrm{Fe}, \mathrm{Cu}, \mathrm{Mn}$ and $\mathrm{Zn}$. The analyzed fungal strains did contribute to a significant increase in $\mathrm{P}$ concentrations in tomato fruit, compared with the control treatment. Fungi of the genera Glomus and Trichoderma ssp. increased the Fe content of tomato fruit by $12.5 \%$
\end{abstract}

*e-mail: majkowska-gadomska@uwm.edu.pl 
and $16.9 \%$, respectively, compared with the control treatment, and Glomus fungi increased also Mn

concentration in tomato fruit.

Keywords: mycorrhiza, fungi, Glomus, Trichoderma ssp., minerals

\section{Introduction}

In the past decade, coco coir, a promising and environmentally friendly growth medium, has become an increasingly popular substrate for growing tomatoes under cover. Cultivation in coco coir is similar to that in rockwool. Coir substrates have excellent physical properties (high water holding capacity and high porosity of approximately 30\%) [1-5].

During cultivation on horticultural substrates, particular attention should be paid to protecting the root system against diseases as well as to strategies for increasing the yield and improving the nutritional value of tomatoes with the use of biostimulants based on e.g. marine algae extracts or live microorganisms. One of the options are mycorrhizal inocula based on association between the roots or other organs and seeds of vascular plants and fungi, referred to as a mycorrhiza. This symbiosis provides benefits to both species because they can share nutrient resources. Plants get easier access to water, mineral salts and growth-regulating substances. In turn, fungi can use glucose produced during photosynthesis. Moreover, mycorrhizas help protect plants against pathogens of the genera Verticillium, Fusarium, Pythium and Rhizoctonia [6-8]. Most studies conducted to date have investigated mycorrhizas present in ornamental, crops, trees and shrubs and orchard plants, whereas mycorrhizal associations in vegetable and food crops remain insufficiently researched [9-11]. Tomatoes (Lycopersicon esculentum Mill.) are widely grown and consumed in many countries around the world. The high quality of tomato fruit is determined by a high content of biologically active compounds, which are a rich source of organic substances and mineral nutrients [6, 12-15].

In the present study, the research hypothesis postulates that mycorrhizal fungal strains can increase the content of phosphorus (P) and selected micronutrients in tomato fruit. The aim of this study was to determine the suitability of three tomato cultivars for growing in a heated plastic tunnel, and the evaluate the influence of fungal strains applied to the rhizosphere of tomato plants on the concentrations of selected minerals, in particular $\mathrm{P}$, iron $(\mathrm{Fe})$, manganese $(\mathrm{Mn})$, copper $(\mathrm{Cu})$ and zinc $(\mathrm{Zn})$, in the fruit.

\section{Materials and Methods}

\section{Experimental}

A two-factorial experiment was conducted in 2015-2016. Tomatoes were grown in coco coir in a heated plastic tunnel in the Experimental Garden of the University of Warmia and Mazury in Olsztyn. The experimental facility was covered with inflated double-layered polyethylene film, and it was equipped with lateral and roof vents, and bottom, side, top and vegetation heating as well as thermal insulation and shade screen systems. Microclimate was controlled automatically with the use of a climate control computer based on readings from a weather station installed on the roof and from sensors located inside the tunnel. After emergence, the temperature was set at $21^{\circ} \mathrm{C}$ during the day and $19^{\circ} \mathrm{C}$ at night. Tomato plants were grown in rain gutters.

The first experimental factor were three tomato cultivars, 'Growdena $\mathrm{F}_{1}$ ', 'Listell $\mathrm{F}_{1}$ ' and 'Torero $\mathrm{F}_{1}$,' suitable for growing in a controlled environment. The second experimental factor was growing tomatoes in coco coir mats with and without fungal strains: control treatment (without fungal strains), growth medium inoculated with fungi of the genus Glomus, growth medium inoculated with a combination of fungi of the genus Trichoderma. The experiment, was carried out in 3 replications, had a split-block design, with 10 plants per replicate in each treatment.

The experimental materials comprised tomato plants grown in the greenhouse of the Department of Horticulture, University of Warmia and Mazury in Olsztyn. The seeds of the analyzed tomato cultivars were sown each year in mid-January. The applied nutrient solution was adjusted to the plants' growth stage and weather conditions. During seedling production: $\mathrm{pH}=5.5, \mathrm{EC}=2.0 \mathrm{mS} \cdot \mathrm{cm}^{-1}, \mathrm{~N}-205, \mathrm{P}-70, \mathrm{~K}-230$, $\mathrm{Mg}-60, \mathrm{Ca}-210\left(\mathrm{mg} \bullet \mathrm{dm}^{-3}\right)$, growth time in the tunnel $\mathrm{pH}=5.5, \mathrm{EC}=3.0 \mathrm{mS} \cdot \mathrm{cm}^{-1}, \mathrm{~N}-220, \mathrm{P}-40, \mathrm{~K}-270$, $\mathrm{Mg}-70, \mathrm{Ca}-220\left(\mathrm{mg} \cdot \mathrm{dm}^{-3}\right)$. It was dispensed into the coco coir mats at 10 -minute intervals at a dose of $66 \mathrm{ml}$ from each dripper to ensure consistent saturation of every mat. Immediately before transplanting (2.03. 2015 and 2016), the root system of each seedling was supplied with $3 \mathrm{~g}$ of mycorrhizal inoculum containing the spores of Glomus fungi. Mycorrhizal inoculum containing Trichoderma spp. spores was applied at $100 \mathrm{ml}$ to the root system of each seedling three times during the growing season, in the form of an aqueous suspension. Trichoderma spp. spores were conditioned for 24 hours before use. Each time, the spore solution was prepared by dissolving $240 \mathrm{~g}$ of the spore formulation in $100 \mathrm{dm}^{3}$ of water at $30^{\circ} \mathrm{C}$. The solution was applied three times during the growing season to promote the colonization of the youngest roots by the fungal spores. 


\section{Plant Materials}

Tomatoes were harvested when fully ripe. During the fully ripe stage, in the first decade of August, average samples (3 $\mathrm{kg}$ of fruit per replicate) were collected from the marketable yield to determine chemical composition of tomato fruit. In order to determine the mineral content of the fruit, plant material was dried at a temperature of $65^{\circ} \mathrm{C}$ and ground in an electric mill. The samples were analyzed in the Chemical and Agricultural Research Laboratory in Olsztyn to determine their content of P were extracted with concentrated sulphuric acid, and then the content of $\mathrm{P}$ was measured colorimetrically with the vanadatemolybdate method (Shimadzu UV 1201V [16] and Fe, $\mathrm{Cu}, \mathrm{Mn}$ and $\mathrm{Zn}-$ by atomic absorption spectrometry (AAS) [17] .

\section{Statistical Analysis}

The mineral content of tomato fruit was analyzed in 2015-2016, and the results were presented as means for the years of the study since only minor differences were noted. The data on the yield and nutritional value of tomato fruit were processed statistically by analysis of variance (ANOVA). The significance of differences was determined by creating multiple confidence intervals in Tukey's test at a significance level of $\alpha=0.05$ [18].

\section{Results and Discussion}

It is higly important to use AMF (arbuscular mycorrhizal fungi) for the production of fruit, vegetable and medicinal crops as AMF increased the accumulation of macroelements $(\mathrm{N}, \mathrm{P})$ and microelements $(\mathrm{Zn}, \mathrm{S}, \mathrm{Cu}$, Fe and Mn) [19]. Symbiotic mycorrhizal fungi colonize the roots of plants, thus increasing the bioavailability of nutrients, including $\mathrm{P}$ and other minerals. The root system colonized by mycorrhizal fungi facilitates nutrient uptake, particularly in soils characterized by relativellow concentrations and solubility of mineral compounds [20-25]. Uptake of different nutrients like phosphorous $(\mathrm{P})$, nitrogen $(\mathrm{N})$, potassium $(\mathrm{K})$, sulfur $(\mathrm{S})$, copper $(\mathrm{Cu})$, Calcium $(\mathrm{Ca})$ and Zinc $(\mathrm{Zn})$ is facilitated by the incorporation of AMF in the soil-plant system [26]. According to Higo et al. [27, 28] phosphorous is highly immobile in plants. Due to the immobile nature of $P$ in soil, application of AMF has the potential to increase agricultural production. $\mathrm{P}$ fertilizer application did not have an influence on root colonization and diversity of the AMF structures in tomato. Root abundance and AMF colonization are correlated negatively. Therefore an investigation is required whether AMF communities and $\mathrm{P}$ fertilization develop more effective management of $\mathrm{P}$ in tomato. Under P deficiency, the fungus supplies P taken from the soil to the plant. Under P deficiency, the fungus supplies $\mathrm{P}$ taken from the soil to the plant. The mycorrhizal mycelium secretes enzymes that are able to solubilize P present in the soil in fixed form, thus making this nutrient available to plants [29-31]. Gnekow and Marschner [30] demonstrated that in P-poor soils, apple cuttings relied on mycorrhizal $\mathrm{P}$ uptake and the mycorrhizal fungus increased $\mathrm{P}$ utilization efficiency, whereas in P-rich soils, the fungal symbiont facilitated the uptake of $\mathrm{Zn}$ and $\mathrm{Cu}$ ions. According to Kyriacou and Rouphael [32], tomatoes are a rich source of minerals. In a study by Banuelos et al. [33], mycorrhizal inoculation of tomato and carrot plants increased their resistance to nematodes, and the weight of mycorrhizal plants was higher than that of non-mycorrhizal control plants. Schroeder and Janos [34] reported that at low P availability, root inoculation with mycorrhizal fungi had a beneficial influence on DM accumulation in tomato plants and cilantro. Sylvia et al. [35] also found that in the low-P soil environment, shoot dry weight was considerably higher in inoculated tomato plants than in non-inoculated control plants.

In the present study, the $\mathrm{P}$ content of tomato fruit was determined by an interaction between the experimental factors (Fig. 1) and the strain of mycorrhizal fungi (Fig. 2). The inoculation with mycorrhizal fungi increase

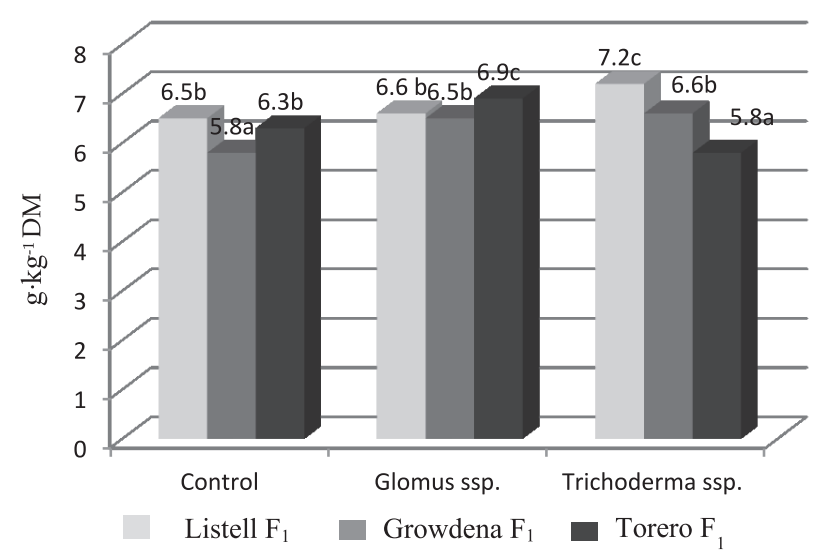

Fig. 1. Phosphorus content in the fruit of three tomato cultivars grown in coco coir mats inoculated with mycorrhizal fungal strains.

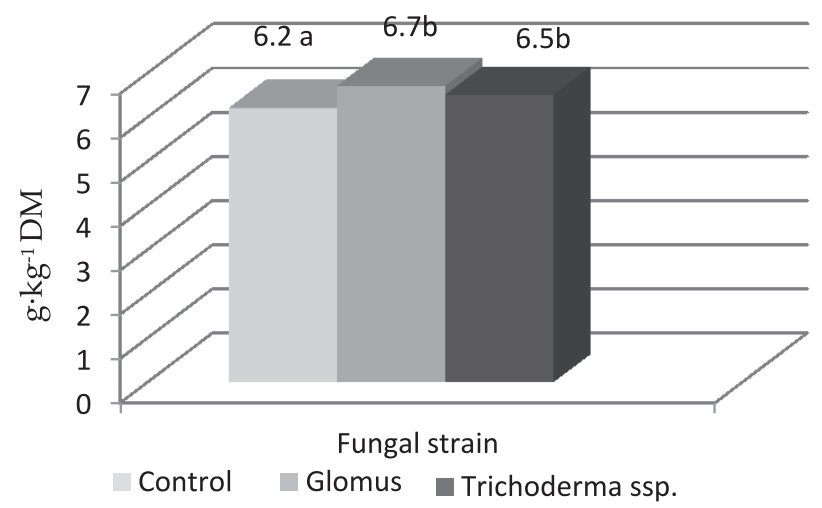

Fig. 2. Phosphorus content in the fruit of tomatoes grown in coco coir mats inoculated with mycorrhizal fungal strains. 
$\mathrm{P}$ concentration, relative to the non-inoculated control treatment. An analysis of the interactions between the experimental factors revealed a similar trend. In tomato plants of cv. 'Listell $\mathrm{F}_{1}$ ' inoculated with Glomus fungi, and in plants of cv. 'Torrero $\mathrm{F}_{1}$ ' inoculated with Trichoderma ssp. fungi, the $\mathrm{P}$ content of fruit was $5.8 \mathrm{~g} \cdot \mathrm{kg}^{-1} \mathrm{DM}$. Apart from control plants, plants of cv. 'Growdena $\mathrm{F}_{1}$ ' inoculated with Trichoderma ssp. strains were most abundant in $\mathrm{P}$. Their $\mathrm{P}$ concentration increased by $15.9 \%$, relative to the treatment with the lowest $\mathrm{P}$ content. Tartanus [36] found that a mycorrhiza had no significant effect on the concentrations of macronutrients and micronutrients in pepper fruit, and it inconsiderably decreased the content of calcium $(\mathrm{Ca})$, $\mathrm{Fe}$ and sodium $(\mathrm{Na})$, relative to the control treatment. Mycorrhizal inoculation of the root system of peppers during seedling production and transplantation caused a minor increase in the concentrations of $\mathrm{P}$, potassium $(\mathrm{K})$, magnesium $(\mathrm{Mg})$ and $\mathrm{Zn}$ in pepper fruit. Borowy et al. [37] demonstrated that a mycorrhiza had no significant effect on the content of nitrogen $(\mathrm{N}), \mathrm{P}, \mathrm{K}, \mathrm{Mg}$ and $\mathrm{Ca}$ in tomato leaves, compared with non-mycorrhizal plants. In a study by Wu et al. [38], Ndung'u- Magiroi et al. [39], Thomson et al. [40] mycorrhizal fungi had a beneficial influence on the concentrations of $\mathrm{K}, \mathrm{Mg}, \mathrm{Fe}$, $\mathrm{Mn}$ and $\mathrm{Zn}$ in the leaves and trunks, and $\mathrm{Ca}$ and $\mathrm{Cu}$ in the trunks of peach trees. In the study Fernandez et.al. [41], the analyzed mycorrhizal fungi contributed to a significant increase in the $\mathrm{Fe}$ content of tomato fruit, compared with the control treatment. Ambroszczyk et al. [42] investigated the effects of various biostimulants on tomato plants and found that the fruit contained 24.83 to $29.10 \mathrm{mg} \cdot 100 \mathrm{~g}^{-1} \mathrm{DM}$ P, 221.5 to $263.8 \mathrm{mg} \cdot 100 \mathrm{~g}^{-1}$ DM K, 11.63 to $20.63 \mathrm{mg} \cdot 100 \mathrm{~g}^{-1} \mathrm{DM} \mathrm{Ca}$, and 5.24 to $6.51 \mathrm{mg} \cdot 100 \mathrm{~g}^{-1} \mathrm{DM} \mathrm{Mg}$. These values are lower than those determined in this study.

In the present experiment, the $\mathrm{Fe}$ content of fruit was higher in cv. 'Growdena $\mathrm{F}_{1}$ ' (56.5 $\mathrm{mg} \cdot \mathrm{kg}^{-1}$ $\mathrm{DM})$ and lower in $\mathrm{cv}$. 'Listell $\mathrm{F}_{1}$ ' (43.5 $\left.\mathrm{mg} \cdot \mathrm{kg}^{-1} \mathrm{DM}\right)$ (Table 1). The concentration of $\mathrm{Zn}$ was significantly highest in the fruit of cv. 'Growdena $F_{1}$ ' $\left(13.4 \mathrm{mg} \cdot \mathrm{kg}^{-1}\right.$ $\mathrm{DM})$, and lowest in $\mathrm{cv}$. Listell $\mathrm{F}_{1}$ ' (7.6 $\left.\mathrm{mg} \cdot \mathrm{kg}^{-1} \mathrm{DM}\right)$. In a study by Dyśko et al. [43], the fruit of cv. 'Growdena $\mathrm{F}_{1}$, had $\mathrm{Fe}$ content of 38.5 to $43.9 \mathrm{mg} \cdot \mathrm{kg}^{-1} \mathrm{DM}, \mathrm{Cu}$ content of 10.4 to $11.9 \mathrm{mg} \cdot \mathrm{kg}^{-1} \mathrm{DM}, \mathrm{Mn}$ content of 21.6 to $25.1 \mathrm{mg} \cdot \mathrm{kg}^{-1} \mathrm{DM}$, and $\mathrm{Zn}$ content of 28.3 to $34.6 \mathrm{mg} \cdot \mathrm{kg}^{-1} \mathrm{DM}$.

In the current study, the analyzed mycorrhizal fungi contributed to a significant increase in the Fe content of tomato fruit, compared with the control treatment. Fungi of the genus Glomus significantly increased the concentrations of $\mathrm{Mn}\left(21.5 \mathrm{mg} \cdot \mathrm{kg}^{-1} \mathrm{DM}\right)$ and $\mathrm{Zn}$ (12.7 $\mathrm{mg} \cdot \mathrm{kg}^{-1} \mathrm{DM}$ ) in the fruit. Acccording to $\mathrm{Al}$ Mutairi et.al. [44], Bhantana et.al. [45] the uptake and use of $\mathrm{Zn}$ are improved by the application of AMF. An analysis of the interactions between the experimental factors revealed a significant increase in the Fe content of fruit in $\mathrm{cv}$. 'Growdena $\mathrm{F}_{1}$ ' in the control treatment and in the treatment with Glomus fungi, and in cv. 'Torero $\mathrm{F}_{1}$ ' inoculated with Trichoderma ssp. fungi.

Table 1. Micronutrient content of tomato fruit depending on cultivar and the applied mycorrhizal fungal strains $\left(\mathrm{mg} \cdot \mathrm{kg}^{-1} \mathrm{DM}\right)$.

\begin{tabular}{|c|c|c|c|c|c|}
\hline \multirow{2}{*}{$\begin{array}{l}\text { Cultivar } \\
\text { (A) }\end{array}$} & \multirow{2}{*}{ Fungal strain(B) } & \multicolumn{4}{|c|}{ Mean values for $2015-2016$} \\
\hline & & $\mathrm{Fe}$ & $\mathrm{Cu}$ & $\mathrm{Mn}$ & $\mathrm{Zn}$ \\
\hline \multirow{4}{*}{ 'Listell $F_{1} '$} & Control & $37.8 \mathrm{a}$ & 3.2 & $19.6 \mathrm{~b}$ & $9.6 \mathrm{~b}$ \\
\hline & Glomus & $44.6 \mathrm{a}$ & $2.8 \mathrm{~b}$ & $21.0 \mathrm{c}$ & $7.2 \mathrm{a}$ \\
\hline & Trichoderma ssp. & $48.0 \mathrm{~b}$ & $2.9 \mathrm{~b}$ & $14.5 \mathrm{a}$ & $6.0 \mathrm{a}$ \\
\hline & Mean & $43.5 \mathrm{a}$ & $3.0 \mathrm{a}$ & $18.4 \mathrm{a}$ & $7.6 \mathrm{a}$ \\
\hline \multirow{4}{*}{ 'Growdena $\mathrm{F}_{1}$ ' } & Control & $54.6 \mathrm{~b}$ & $1.8 \mathrm{a}$ & $19.4 \mathrm{~b}$ & $10.8 \mathrm{c}$ \\
\hline & Glomus & $62.3 \mathrm{c}$ & $2.8 \mathrm{~b}$ & $20.0 \mathrm{~b}$ & $12.8 \mathrm{~d}$ \\
\hline & Trichoderma ssp. & $52.6 b$ & $3.8 \mathrm{c}$ & $21.6 \mathrm{c}$ & $16.6 \mathrm{e}$ \\
\hline & Mean & $56.5 \mathrm{c}$ & $2.8 \mathrm{a}$ & $20.3 \mathrm{a}$ & $13.4 \mathrm{c}$ \\
\hline \multirow{4}{*}{ 'Torero $\mathrm{F}_{1}$ ' } & Control & $40.4 \mathrm{a}$ & $2.4 \mathrm{a}$ & $15.4 \mathrm{a}$ & $6.8 \mathrm{a}$ \\
\hline & Glomus & $44.8 \mathrm{a}$ & $2.6 \mathrm{a}$ & $23.6 \mathrm{c}$ & $18.0 \mathrm{f}$ \\
\hline & Trichoderma ssp. & $59.4 \mathrm{c}$ & $2.6 \mathrm{a}$ & $17.4 \mathrm{a}$ & $6.0 \mathrm{a}$ \\
\hline & Mean & $48.2 b$ & $2.5 \mathrm{a}$ & $18.8 \mathrm{a}$ & $10.3 b$ \\
\hline \multirow{3}{*}{ Mean } & Control & $44.3 \mathrm{a}$ & $2.5 \mathrm{a}$ & $18.1 \mathrm{~b}$ & $9.1 \mathrm{a}$ \\
\hline & Glomus & $50.6 \mathrm{~b}$ & $2.7 \mathrm{a}$ & $21.5 \mathrm{c}$ & $12.7 \mathrm{~b}$ \\
\hline & Trichoderma ssp. & $53.3 \mathrm{~b}$ & $3.1 \mathrm{a}$ & $17.8 \mathrm{a}$ & $9.5 \mathrm{a}$ \\
\hline
\end{tabular}

Means with the same letter do not differ significantly at $\mathrm{p}<0.05$ in Tukey's honest significant difference (HSD) test. 
The concentration of $\mathrm{Fe}$ was significantly lower in the fruit of cvs. 'Listell $\mathrm{F}_{1}$ ' and 'Torero $\mathrm{F}_{1}$ ' in the control treatment and in the treatment with Glomus fungi. An interaction between the experimental factors led to a significant increase in the $\mathrm{Cu}$ content of fruit in $\mathrm{cv}$. 'Listell $\mathrm{F}_{1}$ ' in the control treatment $\left(3.2 \mathrm{mg} \cdot \mathrm{kg}^{-1} \mathrm{DM}\right)$ and in the treatment with Trichoderma ssp. fungi $\left(2.9 \mathrm{mg} \cdot \mathrm{kg}^{-1} \mathrm{DM}\right)$, and in the fruit of $\mathrm{cv}$. 'Growdena $\mathrm{F}_{1}$ ' in the treatment with Trichoderma ssp. fungi (3.8 $\mathrm{mg} \cdot \mathrm{kg}^{-1} \mathrm{DM}$ ). The concentration of $\mathrm{Mn}$ was significantly higher in the fruit of $\mathrm{cv}$. 'Torero $\mathrm{F}_{1}$ ' in the treatment with Glomus fungi (23.6 $\mathrm{mg} \cdot \mathrm{kg}^{-1} \mathrm{DM}$ ), cv. 'Growdena $\mathrm{F}_{1}$ ' in the treatment with Trichoderma ssp. fungi (21.6 $\mathrm{mg} \cdot \mathrm{kg}^{-1} \mathrm{DM}$ ) and cv. 'Listell $\mathrm{F}_{1}$ ' in the treatment with Glomus fungi (21.0 mg. $\left.\mathrm{kg}^{-1} \mathrm{DM}\right)$. Acording to Fernandez [41] regardless of the dose applied, inoculation with AMF led to significant increases in almost all leaf macro- and micro-nutrient concentrations compared to the control treatment. An interaction between the experimental factors induced a significant increase in the $\mathrm{Zn}$ content of fruit in $\mathrm{cv}$. 'Torero $\mathrm{F}_{1}$ ' $\mathrm{F}_{1}$ ' in the treatment with Glomus fungi (18.0 $\mathrm{mg} \cdot \mathrm{kg}^{-1} \mathrm{DM}$ ) and in $\mathrm{cv}$. 'Growdena $\mathrm{F}_{1}$ ' in the treatment with 'Listel $\mathrm{F}_{1}$ ' Trichoderma ssp. strains (16.6 $\left.\mathrm{mg} \cdot \mathrm{kg}^{-1} \mathrm{DM}\right)$. The $\mathrm{Zn}$ content of fruit was significantly lower in tomato plants of cv. 'Listell $\mathrm{F}_{1}$, inoculated with mycorrhizal fungi, and in cv. 'Torero $\mathrm{F}_{1}{ }^{\prime}$ in the control treatment $\left(6.8 \mathrm{mg} \cdot \mathrm{kg}^{-1} \mathrm{DM}\right)$ and in the treatment with Trichoderma ssp. fungi $\left(6.0 \mathrm{mg} \cdot \mathrm{kg}^{-1}\right.$ DM).

\section{Conclusions}

The analyzed fungal strains did contribute to a significant increase in $\mathrm{P}$ concentrations in tomato fruit, compared with the control treatment.

Fungi of the genera Glomus and Trichoderma increased the Fe content of tomato fruit by $12.5 \%$ and $16.9 \%$, respectively, compared with the control treatment, and Glomus fungi increased also $\mathrm{Mn}$ concentration in tomato fruit.

\section{Funding}

The results presented in this paper were obtained as part of a comprehensive study financed by the University of Warmia and Mazury in Olsztyn, Faculty of Agriculture and Forestry, Department of Agroecosystems and Horticulture 30.610.016-110. Project financially supported by Minister of Education and Science in the range of the program entitled "Regional Initiative of Excellence" for the years 20192022, Project No. 010/RID/2018/19, amount of funding 12.000.000 PLN."

\section{Conflict of Interest}

The authors declare no conflict of interest.

\section{References}

1. RAMÍREZ-ARIAS A., PINEDA-PINEDA J., GUTIÉRREZ M., OJEDA-BUSTAMANTE W. Sawdust and coco coir as growing media for greenhouse cherry tomatoes. Acta Horticulturae. 1037, 1063, 2014.

2. www.growconcept.pl [accessed on 10.12.2017]

3. BARTZ W.C., PILL W.G., EVANS T.A. Yield of greenhouse-grown tomato in substrates containing coir and parboiled rice or burnt rice hulls, J. Hortic. Sci. Biotechnol. 92 (3), 231, 2017. https://doi.org/10.1080/14620 316.2016.1271289 [accessed on 10.02.2021]

4. NIKOLAOU G., NEOCLEOUSD., KATSOULAS N., KITTAS C. Irrigation of Greenhouse Crops. Horticulturae. 5 (1), 7, 2019. https://doi.org/10.3390/horticulturae5010007

5. GÓMEZ-BELLOT M.J., LORENTE B., NORTES P., ORTUÑO M.F., SÁNCHEZ-BLANCO M.J., ALARCÓN J.J. Effect of mixed substrate with different mycorrhizal fungi concentrations on the physiological and productive response of three varieties of tomato. Sci. Horticulturae. 283, 2021.

6. SMITH A., BELTRÁN C.A., KUSUNOKI M., COTES A.M., MOTOHASHI K., KONDO T., DEGUCHI M. Diversity of soil-dwelling Trichoderma in Colombia and their potential as biocontrol agents against the phytopathogenic fungus Sclerotinia sclerotiorum (Lib.) de Bary. J. General Plant Pathology. 79, 74, 2013.

7. GHAZANFAR M.U., RAZA M., RAZA W. Misbah Iqbal QamarTrichoderma as potential biocontrol agent, its exploitation in agriculture: A review. Plant Protection. 02 (03), 109, 2018.

8. TSVETKOV I., DZHAMBAZOVA T., KONDAKOVA V., BATCHVAROVA R., Mycorrhizal fungi Glomus spp. and Trichoderma spp. in viticulture (review). Bulg. J. Agric. Sci. 20, 849, 2014.

9. ZHANG, F., YUAN, J., YANG, X., CUI, Y., CHEN, L., RAN, W., SHEN, Q. Putative Trichoderma harzianum mutant promotes cucumber growth by enhanced production of indole acetic acid and plant colonization. Plant and Soil. 368, 433, 2013.

10. PEREIRA J.A.P., VIEIRA I.J.C., FREITAS M.S.M., PRINS C.L., MARTINS M.A., RODRIGUES R. Influence arbuscular mycorrhizal fungi on Capsicum spp. J. Agric. Sci. 154, 828, 2016.

11. ROUPHAEL Y., FRANKEN PH., SCHNEIDER C., SCHWARZ D., GIOVANNETTI M., AGNOLUCCI M., DE PASCALE S., BONINI P., COLLA G. Arbuskular mycorrhizal fungi act as biostimulants in horticultural crops. Sci. Ogrodnicze. 196, 91, 2015.

12. BONA E., CANTAMESSA S., MASSA N., MANASSERO P., MARSANO F., COPETTA A., LINGUA, G., D'AGOSTINO G., GAMALERO E., BERTA G. Arbuscular mikoryzowe grzyby i pseudomonady sprzyjające wzrostowi roślin poprawiają plon, jakość i wartość odżywczą pomidora: badanie terenowe. Mikoryza. 27, 1, 2017.

13. WANG, X., XING, Y. Evaluation of the effects of irrigation and fertilization on tomato fruit yield and quality: a principal component analysis. Sci. Rep. 7, 350, 2017. https://doi.org/10.1038/s41598-017-00373-8 
14. 1JAVARIA S., KHAN M.Q. Impact of integrated nutrient management on tomato yield quality and soil environment. Journal of Plant Nutrition. 34,1, 140, 2010,

15. PANDEY S.K., CHANDRA K.K. Impact of integrated nutrient management on tomato yield under farmers field conditions. Journal of Environmental Biology. 34, 1047, 2013.

16. TYSZKIEWICZ Z.E., CZUBASZEK R., ROJ-ROJEWSKI $\mathrm{S}$. Basic methods of laboratory soil analysis. The script for laboratory classes in the subject of soil science for students of landscape architecture at the University of Technology Białystok. Oficyna Wyd. Politechniki Białostockiej Białystok. 2019.

17. GARCÍA R., BÁEZ A.P., MUHAMMAD AKHYAR FARRUKH (red.) Atomic Absorption Spectrometry (AAS), Atomic Absorption Spectroscopy, InTech, 2012. ISBN: 978-953-307-817-5

18. TIBCO Software Inc. Statistica (Data Analysis Software System, Palo Alto, USA). 2017, Version 13.3. Available online: https://docs.tibco.com/products/tibcostatistica-13-3-0 (accessed on 15 February 2021).

19. CHEN M., ARATO M., BORGHI L., NOURI E., REINHARDT D. Beneficial services of arbuscular mycorrhizal fungi - from ecology to application. Front Plant Sci. 9, 1270, 2018.

20. SAIA S., TAMAYO E., SCHILLACI C., DE VITA P. Arbuscular Mycorrhizal Fungi and Nutrient Cycling in Cropping Systems. W: Datta R., Meena R., Pathan S., Ceccherini M. (red.) Carbon and Nitrogen Cycling in Soil. Springer, 2020. Singapur. https://doi. org/10.1007/978-981-13-7264-3_4

21. CEUSTERMANS A., VAN HEMELRIJCK W., VAN CAMPENHOUT J., BYLEMANS D. Effect of Arbuscular Mycorrhizal Fungi on Pratylenchus penetrans Infestation in Apple Seedlings under Greenhouse Conditions. Pathogens. 7, 66, 2018.

22. BUCHER M. Functional biology of plant phosphate uptake at root and mycorrhiza interfaces. New Phytol. 1, 11, 2007.

23. ZHANG L., FENG G., DECLERCK S. Signal beyond nutrient, fructose, exuded by an arbuscular mycorrhizal fungus triggers phytate mineralization by a phosphate solubilizing bacterium. ISME Journal 12, 2339, 2018

24. AGUILERA P., BORIE F., SEGUEL A., CORNEJO P. Fluorescence detection of aluminium in arbuscular my micorrhizal fung structure and glomalin using confocal laser scan microscopy. Soil Biol. Biochem. 43 (12), 2427, 2011.

25. EMMANUEL O.C., BABALOLA O.O. Productivity and quality of horticultural crops through co-inoculation of arbuscular mycorrhizal fungi and plant growth promoting bacteria. Microbiol.Res. 126569, 2020. https://doi. org/10.1016/j.micres.2020.126569.

26. TURRINI A., AVIO L., GIOVANNETTI M., AGNOLUCCI M. Functional complementarity of arbuscular mycorrhizal fungi and associated microbiota: the challenge of translational research. Front Plant Sci. 9, 1407, 2018.

27. HIGO M., AZUMA M., KAMIYOSHIHARA Y., KANDA A., TATEWAKI Y., ISOBE K. Impact of phosphorus fertilization on tomato growth and arbuscular mycorrhizal fungal communities. Microorganisms 8 (2), 178, 2020. https://doi.org/10.3390/microorganisms8020178

28. HIGO M., SATO R., SERIZAWA A., TAKAHASHI Y., GUNJI K., TATEWAKI Y., ISOBE K. Can phosphorus application and cover cropping alter arbuscular mycorrhizal fungal communities and soybean performance after a five- year phosphorus-unfertilized crop rotational system? Peer J. 6, e4606, 2018 https://doi.org/10.2478/agri-2019-0001

29. WANG Y., WU W.H. Potassium and phosphorus transport and signaling in plants. JIPB. 63 (1), 34, 2021

30. GNEKOW M. A., MARSCHNER H. Role of VAmycorrhiza in growth and mineral nutrition of apple (Malus pumila var. domestica) rootstock cuttings. Plant and Soil. 119, 285, 1989.

31. SATO T., EZAWA T., CHENG W., TAWARAYA K. Release of acid phosphatase from extraradical hyphae arbuskular mycorrhizal fungus Rhizophagus clarus. Soil Sci Plant Nutr. 61 (2), 269, 2015.

32. KYRIACOU M.C., ROUPHAEL Y. Towards a new definition of quality for fresh fruits and vegetables, Scient. Horticult. 234, 463, 2018.

33. BANUELOS J., TREJO-AGUILAR D., ALEJANDRO A. The reduction in proline buildup in mycorrhizal plants affected by nematodes. J.Soil Science and Plant Nutrition. 12, 267, 2012

34. SCHROEDER M.S., JANOS D.P. Phosphorus and intraspecific density alter plant responses to arbuscular mycorrhizas. Plant and Soil. 264, 335, 2004.

35. SYLVIA D.M., ALAGELY A.K., CHELLEMI D.O., DEMCHENKO L.W. Arbuscular mycorrhizal fungi influence tomato competition with bahiagrass. Biol. Fertil. Soils. 34, 448, 2001.

36. TARTANUS M. The influence of mycorrhizal fungi and super-sorbents for the growth and yielding of pepper (Capsicum annuиm L.). Doctoral dissertation. Manuscript. 2017.

37. BOROWY A., KAPŁAN M., RULAK M. The impact of mycorrhizal inoculation on the growth and yield of stake tomato under field cultivation. Ann. UMCS Sec. EEE Hort. 23 (2), 1, 2015.

38. WU J., WANG D., ROSEN C.J., BAUER M.E. Comparison of petiole nitrate concentrations, SPAD chlorophyll readings, and QuickBird satellite imagery in detecting nitrogen status of potato canopies. Field Crop Res. 101, 96, 2007.

39. NDUNG'U-MAGIROI K.W., HERMANN L., OKALEBO J.R., OTHIENO, C.O., PYPERS P., LESUEUR D. Occurrence and genetic diversity of phosphate-solubilizing bacteria in soils of different chemical characteristics in Kenia. Ann. Microbiol. 62, 897, 2012.

40. THOMPSON J.P., CLEWETT T.G. FISKE, M.L. Field inoculation with arbuscular-mycorrhizal fungi overcomes phosphorus and zinc deficiencies of linseed (Linum usitatissimum) in a vertisol subject to long-fallow disorder. Plant Soil. 371, 117, 2013.

41. FERNÁNDEZ F., VICENTE-SÁNCHEZ J., MAESTREVALERO J.F., BERNABÉ A.F., NICOLÁS E., PEDRERO F., ALARCÓN J.J. Physiological and growth responses of young tomato seedlings to drip-irrigation containing two low doses of the arbuscular mycorrhizal fungus Glomus iranicum var. tenuihypharum sp. Nova. J. Horticult. Sci. \& Biotech. 89 (6) 679, 2014.

42. AMBROSZCZYK A.M., LIWIŃSKA E., BIEŻANOWSKA-KOPEĆ E. Differentiation of values the nutritional and health-promoting fruit of tomato $\mathrm{V}$ depending on the growth stimulants used. In: The role of technological processes in shaping quality food.. Red.: Duda-Chodak A., Najgebauer-Lejko D., Drożdż I., Tarko T.: 173, 2016.

43. DYŚKO J., KANISZEWSKI S., KOWALCZYK W., DZIEDZICZAK K., KOWALSKI B., MORACZEWSKI A., PODSIEDLNIK W., WOJTYSIAK J. Ecological 
fibrous soilless substrates in greenhouse crops. Probl. Ekspl. 2, 37, 2012.

44. AL MUTAIRI A.A., CAVAGNARO T.R., KHOR S.F., NEUMANN K., BURTON R.A., WATTS-WILLIAMS S.J. The effect of zinc fertilisation and arbuscular mycorrhizal fungi on grain quality and yield of contrasting barley cultivars. Funct. Plant Biol. 47 (2), 122, 2020. https://doi.org/10.1071/FP19220
45. BHANTANA P., RANA M.S., SUN X.C. MOUSSA M.G., SALEEM M.H., SYAIFUDIN M., SHAH A., POUDEL A., PUN A.B., BHAT M.A., MANDAL D.L., SHAH S., ZHIHAO D., TAN Q., HU C.X. Arbuscular mycorrhizal fungi and its major role in plant growth, zinc nutrition, phosphorous regulation and phytoremediation. Symbiosis. 2021. https://doi.org/10.1007/s13199-021-00756-6 (accessed on 5 May 2021). 
